\begin{tabular}{|c|c|}
\hline 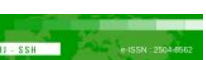 & Malaysian Journal of Social Sciences and Humanities (MJSSH) \\
\hline Malaysian Journal of & Volume 6, Issue 6, June 2021 \\
\hline (MJ-sSH) & e-ISSN : 2504-8562 \\
\hline & $\begin{array}{l}\text { Journal home page: } \\
\text { www.msocialsciences.com }\end{array}$ \\
\hline
\end{tabular}

\title{
Using Capital Budgeting Method to Solve Financial Problems in Natural Perfume Business: A Case Study from Adem Fresh
}

\author{
Didid Rogianantoํㅜ, Acip Sutardi ${ }^{1}$ \\ ${ }^{1}$ School of Business and Management, Institut Teknologi Bandung, Indonesia \\ Correspondence: Didid Rogiananto (didid_rogiananto@sbm-itb.ac.id)
}

\begin{abstract}
The purpose of this research is to solve financial problems that exist in Adem Fresh. Adem fresh is a business that provides natural products in the form of perfume, by using fermentation Adem Fresh can process fruits and vegetables into perfume seeds. Based on the analysis problems that have been carried out, the main problems for Adem Fresh are limited funds and resources. Therefore the use of capital budgeting and risk analysis is used to solve existing problems. Risk analysis is used to determine risk priorities and to reduce losses if such risks occur, while capital budgeting is used to assess whether the business is financially feasible or not. This research is structured using descriptive quantitative method, where in this study it does not prove a hypothesis but the researcher focuses on solving problems by describing solution based on existing data. The data taken in this study include financial data from Adem Fresh in 2020 and 2021, journals and books, expert opinions and also previous studies. With this research, it is hoped that it will have implications for the Adem Fresh business. First, the results of the feasibility analysis can be used as a consideration for owners regarding the Adem Fresh business. Second, with the existence of risk analysis, it can reduce the losses incurred because there is already a prepared mitigation and finally in this study an implementation plan is also prepared to answer the problems experienced by the Adem Fresh business.
\end{abstract}

Keywords: feasibility business, risk analysis, capital budgeting, tech-business

\section{Introduction}

Adem Fresh is a business that is engaged in the green consumer good industry, currently Adem Fresh releases a product in the form of perfume made from natural ingredients. The main value of Adem Fresh is perfume with high quality and made from natural ingredients, so it is safe to use for customers and safe for the environment. The target market of Adem Fresh in general is Indonesian people of productive age aged 15 to 37 years, but in a niche, people who care about the environment and support the zero waste movement.

In this study, the researcher wanted to analyze several things related to the problems experienced by Adem Fresh. First, researcher want to find what risks Adem Fresh needs to prioritize. Second, researchers also want to know the business feasibility from a financial perspective through capital budgeting. Finally, researchers can make decisions related to business development based on risk analysis and capital budgeting. 


\section{Business Issued Faced}

Adem Fresh as a Small Medium Enterprise (SME) has very limited resources, therefore proper use of resources and making the right decisions are needed so that existing resources can be used appropriately and useful. Making the right decisions and also using good resources will also affect the costs incurred by Adem Fresh to cover projects that provide more benefits to the business.

Risk analysis is used to find out what risks need to be a concern for Adem Fresh and in the end it can implement business strategies for business progress. Capital budgeting is used because currently Adem Fresh wants to know the future business forecast and also the proper financial allocation for the project. At the end, on the analysis feasbility with the help of risk analysis and capital budgeting will implement what strategies can be used Adem Fresh to develop business in accordance with the existing resource.

\section{Literature Review}

\section{Risk Analysis}

Risk is defined as an event that is uncertain and has a possible influence on a project within a company, risks that have been identified and also analyzed are likely to reduce the impact of these risks for the company (Rezakhani, 2012). Risk is a measure of uncertainty in the return on investment, an investment decision will usually consider risk before taking it (Gitman \& Zutter, 2014).

\section{Risk Assessment Tools}

Companies need to identify what factors cause these risks to arise and determine how to manage these risk (Kieso et al., 2014). Before the assessment stage, a company must first analyze the risks that affect business continuity. In risk assessment, there are 2 methods that can be done, through qualitative and quantitative approaches (Shenkir \& Walker, 2007).

\section{Capital Budgeting}

Capital budgeting is a process of evaluating and selecting long-term investments with the aim of improving company performance (Gitman \& Zutter, 2014). ). Researchers use the capital budgeting method to assist Adem Fresh in improving the company's future performance. Currently Adem Fresh is experiencing many problems, especially related to making investment decisions for the future. With good capital budgeting for Adem Fresh, it is hoped that it can improve the company's performance and help make good decisions for Adem Fresh.

\section{Payback Period}

The payback period is the time required to return an initial investment in a project, the payback period is calculated from the company's cash inflow. In calculating the payback period, the time value of money is ignored (Gitman \& Zutter, 2014).

The decision of a project is accepted / rejected when viewed in the payback period as follows (Gitman \& Zutter, 2014) :

a. If the payback period is less than the maximum value of the company's standard payback period, the project is accepted.

b. If the payback period is more than the maximum value of the company's standard payback period, the project is rejected.

* The maximum value of the payback period is subjective depending on the company.

\section{Net Present Value}


Net Present Value is one of the techniques of capital budgeting, the value of Net Present Value is obtained from reducing the present value of cash inflows that have been discounted at the same level as the company's cost of capital (Gitman \& Zutter, 2014).

$$
N P V=\sum_{t=1}^{N} \frac{R_{t}}{(1+i)^{t}}
$$

Source : (Gitman \& Zutter, 2014)

In making investment decisions, companies need to consider the following (Gitman \& Zutter, 2014):

a. If the NPV value is more than 0 the project is accepted.

b. If the NPV is less than 0 the project is rejected.

NPV of more than 0 indicates that a project will bring more income to a company and can improve company performance capital

\section{Internal Rate of Return}

Internal Rate of Return is one of the calculation techniques for Capital Budgeting. IRR is a discount rate which assumes that the NPV in a project is equal to 0 (because the present value of cash inflow is equal to the initial investment) (Gitman \& Zutter, 2014).

$$
I R R=i_{1}+\frac{N P V_{1}}{\left(N P V_{1}-N P V_{2}\right)}\left(i_{2}-i_{1}\right)
$$

Source : (Gitman \& Zutter, 2014)

In making a decision, the following should be considered (Gitman \& Zutter, 2014):

a. If the IRR is more than the cost of capital, the investment is accepted.

b. If the IRR is less than the cost of capital, the investment is rejected.

\section{Conceptual Framework}

Problem identification and root cause analysis are based on the current conditions of Adem Fresh and with the help of a fishbone diagram researcher will determine the root causes of problems from Adem Fresh. Then explore the problem and form a solution using risk analysis and capital budgeting. Performing a risk analysis can help estimate the probability of uncertainty that will occur, so that the output will help secure the company's resources (Del Giudice et al., 2014). Capital budgeting is a process of evaluation, selection and determination of investment that provides more benefits to companies in more than one year (Gitman \& Zutter, 2014). The researcher wants to use risk analysis to reduce the impact of losses incurred in the future and capital budgeting analysis as a tool to determine the feasibility of the Adem Fresh business. 
Figure 1: Conceptual Framework

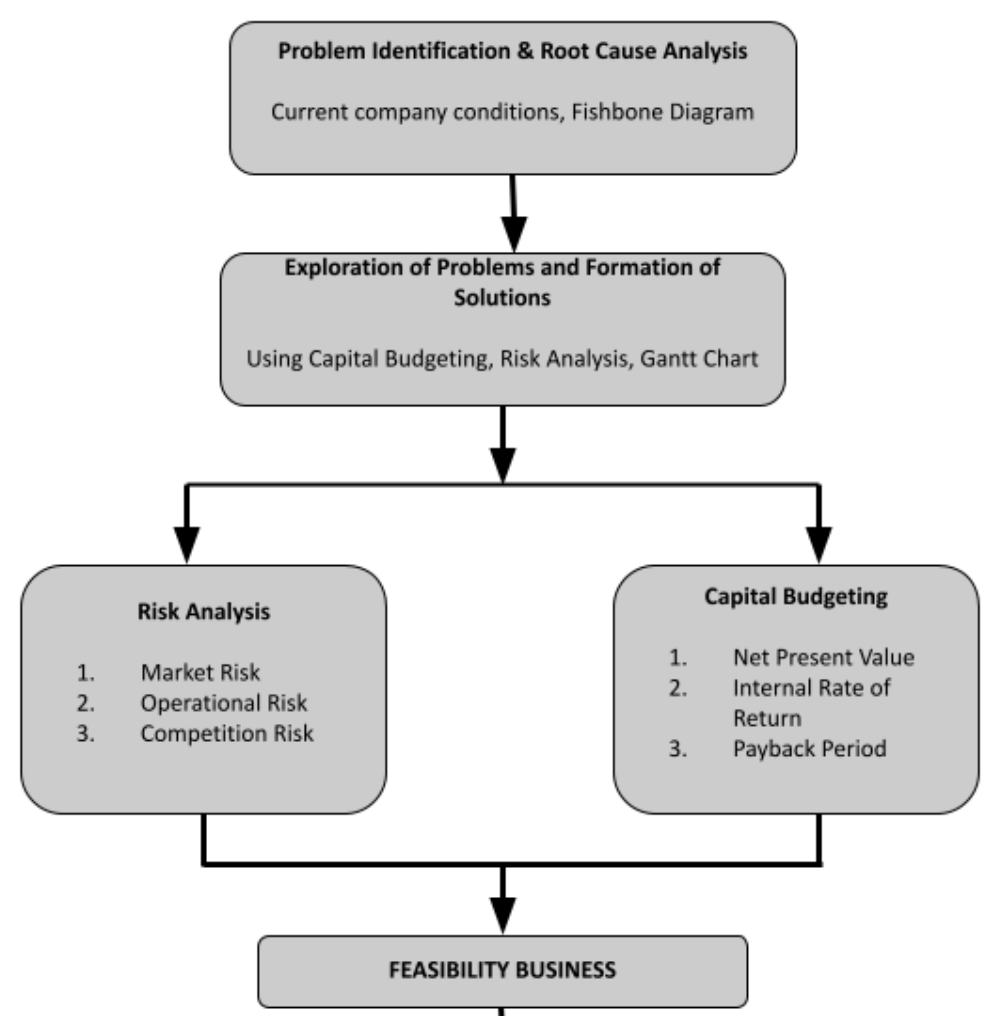

\section{Methodology}

The method used in this research is quantitative descriptive method. Research using quantitative descriptive is a study that does not look for a correlation or relationship, nor is it a research that aims to test hypotheses (Hasanah, 2017). The purpose of using quantitative descriptive methods in this research is to describe the problems and solutions in Adem Fresh related to the company's financial sector. This research begins with problem identification, at this stage it will be known what the main problem and the root cause of the Adem Fresh business problem. Researchers use fishbone diagram tools to help find the root cause problem. The analysis of this problem will include internal and external Adem Fresh company.

After doing problem identification, the next is a theoretical foundation. The theoretical foundation is used to support arguments and also a reference in solving a problem. The theoretical foundations used in this study are expert opinions as well as several theories related to risk analysis and capital budgeting. For data collection, 2 sources were used which are primary and secondary sources. Primary data is a source of data that is obtained directly by researchers. In obtaining the data, the researcher can do several methods, such as surveys, FGDs, interviews and so on (Tamarin \& Mwamadzingo, 2011). In this study, researchers obtained data directly in the form of financial reports from Adem Fresh from 2020 to 2021. Secondary data is obtained from the evaluation and reviewing process of previous research, or it could be using the approach of several literatures such as books and journals (Johnston, 2014). In this study, researchers will use secondary data from journals, books or previous research as a reference in solving problems.

From the data that has been obtained, to process the data will use capital budgeting and risk analysis. Risk analysis includes market risk, operational risk and competitive risk. Meanwhile, capital budgeting will be processed using the NPV, IRR and payback period tools. 


\section{Analysis and Result}

\section{Risk Measurement}

Assessing risk can be seen from 2 sides, which are probability and impact. This is also the basis for researchers to determine measurement in assess risk in Adem Fresh. There are no definite provisions in setting the numbers in the measurement, all are adjusted to the conditions of the respective companies (Shenkir \& Walker, 2007).

Table 1: Adem Fresh's Probability Risk Measurement

\begin{tabular}{clc}
\hline \multicolumn{2}{c}{ Probability } & Probability / year \\
\cline { 1 - 2 } Level & \multicolumn{1}{c}{ Category } & $>30$ cases \\
5 & Almost certain & $21-30$ cases \\
4 & Likely & $11-20$ cases \\
3 & Moderate & $5-10$ cases \\
2 & Unlikely & $<5$ cases \\
1 & Rare &
\end{tabular}

To measure impact, the researcher uses a specific measure in the form of an estimate of the loss resulting from this risk (estimated conversion if it is expressed in Rupiah). For details on the size of the impact, see the table below.

Table 2: Adem Fresh's Impact Risk Measurement

\begin{tabular}{ccc}
\hline \multicolumn{2}{c}{ Impact (Losses) } & Loss Expectation (in Rupiah) \\
\cline { 1 - 2 } Level & Criteria & Rp. 100,000,000 \\
\hline 5 & Catastrophic & Rp. 75,000,001 - Rp. 100,000,000 \\
4 & Major & Rp. 50,000,001 - Rp. 75,000,000 \\
3 & Moderate & Rp. 25,000,001 - Rp. 50,000,000 \\
2 & Minor & $<$ Rp. 25,000,000 \\
1 & Insignificant &
\end{tabular}

Source: Susanto et al. (2019)

\section{Risk Assessment}

Based on the measurement that has been made by the researcher, the next step is to assess the risks that have been identified. The purpose of a risk assessment is to find out which risks need to be prioritized based on their probability and impact. Knowing the priority risks will also provide insight for Adem Fresh to use its resources based on priority.

Table 3: Adem Fresh's Risk Asessment

\begin{tabular}{lllll}
\hline $\begin{array}{l}\text { Risk } \\
\text { Number }\end{array}$ & Area & Detail & Probability Impact \\
\hline 1 & \multirow{3}{*}{ Market Risk } & Market price sensitive & 5 & 5 \\
& $\begin{array}{l}\text { Changes in Habits Due to the Covid-19 } \\
\text { Pandemic }\end{array}$ & 2 & 5 \\
3 & Operation Risk & The risk of delays in the business scale up & 1 & 5 \\
\hline
\end{tabular}


DOI: https://doi.org/10.47405/mjssh.v6i6.828

\begin{tabular}{lllll}
\hline 4 & The high cost of shipping products out of Java & 4 & 4 \\
5 & $\begin{array}{l}\text { Competition } \\
\text { Risk }\end{array}$ & Risk of price wars with competitors & 4 & 3 \\
\hline
\end{tabular}

\section{Risk Mapping and Mitigation}

After assessing risk, the researchers conducted a risk mapping to make it easier to see which risks are in the high category and which risks can be ignored.

Figure 2: Adem Fresh's Risk Mapping

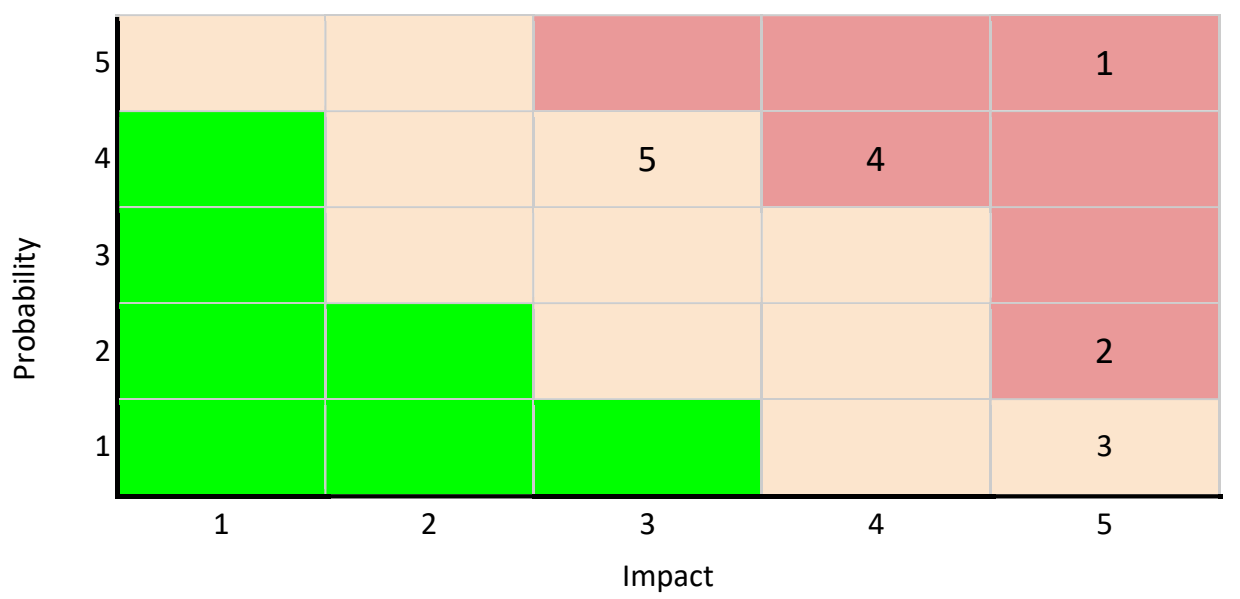

Table 4. Adem Fresh's Risk Priority

\begin{tabular}{lll}
\hline Order to- & Name of Risk & Risk category \\
\hline 1 & Market price sensitive & High \\
2 & The high cost of shipping products out of Java & High \\
3 & Changes in Habits Due to the Covid-19 Pandemic & High \\
4 & Risk of price wars with competitors & Medium \\
5 & The risk of delays in the business scale up & Medium \\
\hline
\end{tabular}

Based on the risk assessment and risk mapping that has been carried out, at this stage the researcher proposes to mitigate the existing risks. The formulation of risk mitigation was prepared by researchers aimed at reducing the impact that occurs because of the risks that arise.

Table 5. Adem Fresh's Risk Mitigation

\begin{tabular}{|c|c|c|c|c|}
\hline \multicolumn{5}{|c|}{ Adem Fresh Risk Mitigation } \\
\hline Number & Area & Detail & Threats to Companies & Mitigation \\
\hline 1 & & $\begin{array}{l}\text { Market price } \\
\text { sensitive }\end{array}$ & $\begin{array}{l}\text { It is easy to switch the } \\
\text { market to another brand, } \\
\text { the proportion of the } \\
\text { market size can be reduced. }\end{array}$ & $\begin{array}{l}\text { Doing economies of scale to } \\
\text { get cheap production costs, } \\
\text { Offer special prices to attract } \\
\text { customers. }\end{array}$ \\
\hline 2 & Market Risk & $\begin{array}{l}\text { Changes in } \\
\text { Habits Due to the } \\
\text { Covid-19 } \\
\text { Pandemic }\end{array}$ & $\begin{array}{l}\text { Changing the usual habit of } \\
\text { using perfume outside the } \\
\text { home can reduce the }\end{array}$ & $\begin{array}{l}\text { Conducting campaigns and } \\
\text { education about the benefits } \\
\text { of using perfume even }\end{array}$ \\
\hline
\end{tabular}


DOI: https://doi.org/10.47405/mjssh.v6i6.828

\begin{tabular}{|c|c|c|c|c|}
\hline \multirow{3}{*}{3} & \multirow{3}{*}{$\begin{array}{l}\text { Operation } \\
\text { Risk }\end{array}$} & & $\begin{array}{l}\text { number of sales of Adem } \\
\text { Fresh }\end{array}$ & $\begin{array}{l}\text { though customers work from } \\
\text { home. }\end{array}$ \\
\hline & & $\begin{array}{l}\text { The risk of } \\
\text { delays in the } \\
\text { business scale up }\end{array}$ & $\begin{array}{l}\text { Missed the opportunity to } \\
\text { get above average sales }\end{array}$ & $\begin{array}{l}\text { Cooperate with third parties } \\
\text { (makelon) if the market } \\
\text { needs are booming later. }\end{array}$ \\
\hline & & $\begin{array}{l}\text { The high cost of } \\
\text { shipping products } \\
\text { out of Java }\end{array}$ & $\begin{array}{l}\text { Lost opportunities to get } \\
\text { customers outside Java, lost } \\
\text { opportunities to increase } \\
\text { sales. }\end{array}$ & $\begin{array}{l}\text { Providing distributors for } \\
\text { several cities outside Java, so } \\
\text { that shipments can be made } \\
\text { directly on the island. }\end{array}$ \\
\hline 4 & $\begin{array}{l}\text { Competition } \\
\text { Risk }\end{array}$ & $\begin{array}{l}\text { Risk of price } \\
\text { wars with } \\
\text { competitors }\end{array}$ & $\begin{array}{l}\text { Losing customer loyalty, } \\
\text { it's easy to switch } \\
\text { customers to other brands }\end{array}$ & $\begin{array}{l}\text { Performing competitor } \\
\text { intelligence (regularly track } \\
\text { what competitors are doing), } \\
\text { Providing attractive offers } \\
\text { related to price. }\end{array}$ \\
\hline
\end{tabular}

Source: Author's Analysis

\section{Feasibility Analysis}

\section{Sales Projection}

In determining sales projections for the next 5 years the researcher uses several assumptions to strengthen the formation of the sales projection, these assumptions are based on historical sales data and also other supporting data outside the Adem Fresh company. First, from the historical data on sales of Adem Fresh for 2020-2021, in general, it has increased by an average of $22 \%$, this is at the same time a benchmark in the pessimistic scenario, researchers consider that monthly growth should not exceed 22\%. During 20212025 , it is predicted that beauty products, including natural products in Indonesia, will increase annually by $6.46 \%$.(Statista, 2021). That way, in compiling a sales projection, it is assumed that each year it will increase by $6 \%$ from the previous year.

Table 6: Adem Fresh's Sales Projection

\begin{tabular}{cccc}
\hline & \multicolumn{3}{c}{ Sales Projection } \\
\cline { 2 - 4 } Year & Pessimistic & Volume & Optimistic \\
\cline { 2 - 4 } 1 & 1.495 & 1.824 & 1.854 \\
2 & 1.585 & 1.933 & 1.965 \\
3 & 1.680 & 2.049 & 2.083 \\
4 & 1.781 & 2.172 & 2.208 \\
5 & 1.887 & 2.303 & 2.340 \\
\hline
\end{tabular}

\section{Proforma Cashflow}

In calculating NPV and IRR, the researcher uses Net Income which has calculated the time value of money according to the current interest rate in Indonesia (Where, the loan interest set by Bank Indonesia as of 2021 is 3.5\%). Meanwhile, the Payback Period of the researcher calculates the Net Changes in Cash in Proforma Cash Flow. To determine the cost of capital, the researcher calculates the Weighted Averaged Cost of Capital (WACC). Where to take into account the Cost of Debt and Capital Asset Pricing Model (CAPM). The CAPM formula is as follows. Based on the calculation, the WACC is $3 \%$.

Where,

$$
R a=R r f+[\beta a \times(R m-R r f) I]
$$

$R a=$ Cost of Equity 
Rrf $=$ Risk Free Rate

$B a=$ Beta Industry

$R m=$ Market Rate of Return

Table 7: Net Income Projection

\begin{tabular}{|c|c|c|c|}
\hline \multirow{3}{*}{ Year } & \multicolumn{3}{|c|}{ Net Income Projection } \\
\hline & \multicolumn{3}{|c|}{ Scenario } \\
\hline & Pessimistic & Most- Likely & Optimistic \\
\hline 1 & Rp34.532.221 & Rp43.019.719 & Rp43.825.087 \\
\hline 2 & Rp36.846.993 & Rp45.843.741 & Rp46.661.627 \\
\hline 3 & Rp39.300.652 & Rp48.837.204 & Rp49.704.163 \\
\hline 4 & Rp41.901.530 & Rp52.010.275 & Rp52.929.252 \\
\hline 5 & Rp44.658.460 & Rp55.373.730 & Rp56.347.846 \\
\hline
\end{tabular}

Table 8: Cash Flow Projection

\begin{tabular}{llll}
\hline & \multicolumn{3}{c}{ Cash Flow Projection } \\
\cline { 2 - 4 } & \multicolumn{3}{c}{ Scenario } \\
\cline { 2 - 4 } & \multicolumn{1}{c}{ Pessimistic } & \multicolumn{1}{c}{ Most- Likely } & \multicolumn{1}{c}{ Optimistic } \\
\hline 1 & Rp27.843.471 & Rp36.330.969 & Rp37.136.337 \\
2 & Rp30.158.243 & Rp39.154.991 & Rp40.187.474 \\
3 & Rp32.611.902 & Rp42.148.454 & Rp43.230.011 \\
4 & Rp35.212.780 & Rp45.321.525 & Rp46.455.099 \\
5 & Rp37.969.710 & Rp48.684.980 & Rp49.873.693 \\
\hline
\end{tabular}

To determine whether a project is acceptable or not, the first thing the researcher does is to set the level of acceptance for each measure. By using the NPV, IRR and payback period measures, the measures used as the basis for project acceptance are as follows.

Table 9: Feasibility Measurement

\begin{tabular}{cclll}
\hline \multirow{3}{*}{ Criteria } & \multicolumn{1}{c}{ NPV } & \multicolumn{1}{c}{ IRR } & Payback Period & \multicolumn{1}{c}{ Decision } \\
\cline { 2 - 5 } & NPV>0 & $\begin{array}{l}>3 \%(\text { Value of Cost of } \\
\text { Capital) }\end{array}$ & Less than 5 years & $\begin{array}{l}\text { Project will be } \\
\text { accepted }\end{array}$ \\
\hline
\end{tabular}

The project will be accepted if the NPV value is more than 0 , then the payback period is not less than 5 years and the IRR is more than $3 \%$. After determining the size of revenue, the calculation results and decisions on the business are as follows.

Table 10. Adem Fresh's Feasibility Result

\begin{tabular}{rrrrr}
\hline & Result & \\
& NPV (Rp) & IRR & $\begin{array}{c}\text { Payback } \\
\text { Period (Years) }\end{array}$ & Decision \\
\hline Pessimistic Scenario & Rp110.436.952 & $43 \%$ & 2,3 & Project Accepted \\
\hline
\end{tabular}




\begin{tabular}{lllll} 
Most Likely Scenario & Rp153.468.573 & $58 \%$ & 1,8 & Project Accepted \\
Optimistic Scenario & Rp157.413.173 & $59 \%$ & 1,7 & Project Accepted \\
\hline
\end{tabular}

From the above results it can be seen that the value of all scenarios meets the acceptance criteria of the project. And the conclusion that can be drawn is that the project is accepted and feasible to continue. That way the owner can take insight from Adem Fresh to continue this business because it will still provide good profits

\section{Conclusion}

From the risk analysis that has been carried out, starting from risk identification to mapping the main risks that have a high probability and impact comes from market risk, which is a market that is sensitive to price. Therefore, at risk mitigation, the researcher proposes to purchase raw materials with the principle of economics of scale so that it will get cost effective and can offer low prices to the market.

In terms of financial feasibility analysis, researchers use 3 measures to determine whether the business is feasible or not. The three measures are Net Present Value (NPV), Internal Rate of Return and payback period. NPV will be accepted if the value is more than 0, IRR will be accepted if the value is more than $3 \%$ and the payback period will be accepted if the value is not more than 5 years. The researcher makes a cash flow projection for the next 5 years as the basis for calculating the feasibility analysis. Based on the results, it shows that all projects in both the pessimistic, most likely and optimistic scenarios meet the criteria. In the pessimistic scenario, the NPV value is Rp. 110,436,952, the IRR value is $43 \%$ and the payback period is 2.3 years. While in the most likely scenario: the NPV value is Rp. 153,468,573, the IRR value is $58 \%$ and the payback period is 1.8 years. In the optimistic scenario, the NPV value is $157,413,173$, the IRR value is $59 \%$ and the payback period is 1.7 years. All scenarios meet the criteria and it can be concluded that the Adem Fresh business is feasible.

\section{References}

Anisah, D., Herliati, \& Widyaningrum, A. (2014). 1097-2134-1-Sm. Pemanfaatan Sampah Sayuran Sebagai Bahan Baku Pembuatan Bioetanol, 13-18.

Asngali, B., \& Subagyo, C. A. (2018). Pemanfaatan Limbah Buah Salak Sebagai Bahan Bakar Bioethanol. JEECAE (Journal of Electrical, Electronics, Control, and Automotive Engineering), 3(1), 167-172. https://doi.org/10.32486/jeecae.v3i1.208

Atan, H., Ramly, E. F., Mohammad, M., \& Yahya, M. S. (2017). A review of operational risk management decision support tool. Proceedings of the International Conference on Industrial Engineering and Operations Management, 2669-2680.

Bakke, K. (2017). Technology readiness levels use and understanding. Incose, 11(2017), 31. https://brage.bibsys.no/xmlui/handle/11250/2452831

Bchini, B. (2014). Entrepreneurship: A Key to Minimizing The Risks Of Tunisian Family Businesses. Journal of Business Studies Quarterly, 5(4), 68-80. http://search.ebscohost.com/login.aspx?direct=true \&db=bth\&AN=96783707\&site=ehost-live

Boitnott, J. (2019). 7 Business Risks Every Business Should Plan For. https://www.americanexpress.com/en-us/business/trends-and-insights/articles/7-business-risksevery-business-should-plan-for/

Coccia, M., \& Niversity, A. R. S. T. U. (2017). The Fishbone diagram to identify, systematize and analyze the sources of general purpose technologies. The Fishbone Diagram to Identify, Systematize and Analyze the Sources of General Purpose Technologies, 4(4), 291-303. https://doi.org/10.1453/jsas.v4i4.1518

Conroy, R. (2009). Financial Forecasting. Darden Case, 4(3), 371-374.

Del Giudice, V., Passeri, A., Torrieri, F., \& De Paola, P. (2014). Risk analysis within feasibility studies: An application to cost-benefit analysis for the construction of a new road. Applied Mechanics and 
Materials, 651-653, 1249-1254. https://doi.org/10.4028/www.scientific.net/AMM.651-653.1249

Fasterholdt, I., Lee, A., \& Kjeld, P. (2018). Defining early with Technology Readiness Levels (TRL) based on early... | Download Scientific Diagram. https://www.researchgate.net/figure/Defining-earlywith-Technology-Readiness-Levels-TRL-based-on-early-NASA-model_fig1_328777621

Feasibility Study Definition. (n.d.). Retrieved February 12, 2021, from https://www.investopedia.com/terms/f/feasibility-study.asp

Five Reasons Why A Feasibility Study Is Important | SFA. (n.d.). Retrieved February 12, 2021, from https://sportadvisory.com/feasibility-study-five-reasons-need-conduct-one/

Gerstell, E., Marchessou, S., Schmidt, J., \& Spagnuolo, E. (2020). How COVID-19 is changing the world of beauty. McKinsey \& Company, Consumer Packaged Goods Practice, 1(May), 1-8.

Gitman, L. J., \& Zutter, C. J. (2014). Managerial Finance. In The Journal of Finance (Vol. 17, Issue 4). https://doi.org/10.2307/2977800

Gropp, R., Hakenes, H., \& Schnabel, I. (2011). Competition, risk-shifting, and public bail-out policies. Review of Financial Studies, 24(6), 2084-2120. https://doi.org/10.1093/rfs/hhq114

Gupta, D., \& Pradhan, B. (2017). Capital Budgeting Decisions in India: Manufacturing Sector versus Non-Manufacturing Sector. IUP Journal of Applied Finance, 23(1), 69.

Haque, K. M. R. (2011). Exploring Price Sensitivity of a Green Brand : A Consumers' Perspective World Review of Business Research Exploring Price Sensitivity of a Green Brand: A Consumers ' Perspective. World Review of Business Research Vol. 1. No. 2. May 2011 Pp. 84 - 97, May 2011.

Herrera, M. (2013). Four Types of Risk Mitigation and BCM Governance, Risk and Compliance. https://www.mha-it.com/2013/05/17/four-types-of-risk-mitigation/

IDX, 2020. (n.d.). 3,5 Juta Orang Kehilangan Pekerjaan Akibat Pandemi Covid-19. In IDXchannel.com. Retrieved April 22, 2021, from https://www.idxchannel.com/market-news/35-juta-orangkehilangan-pekerjaan-akibat-pandemi-covid-19

Istiqomah, M., \& Marlena, N. (2020). Pengaruh promo gratis ongkos kirim dan online customer rating terhadap keputusan pembelian produk fashion The effect of free shipping promotion and online customer rating on the purchase decision of fashion product. Jurnal Manajemen, 12(2), 288-298.

Janvier-James, A. M. (2011). A New Introduction to Supply Chains and Supply Chain Management: Definitions and Theories Perspective. International Business Research, 5(1), 57-65. https://doi.org/10.5539/ibr.v5n1p194

Johnston, M. P. (2014). Secondary Data Analysis : A Method of which the Time Has Come. Qualitatve and Quantative Methods in Libraryes (QQML), 3, 619-626. 